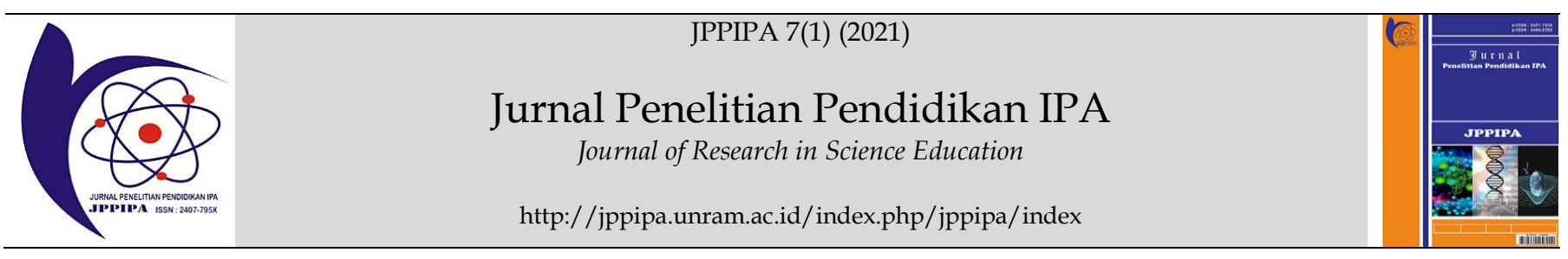

\title{
Synthesis of M-Hexaferrites Material Based on Natural Iron Sand with Metal Co Doping Using the Coprecipitation Method
}

\author{
Susilawati ${ }^{1,2^{*}}$, Aris Doyan ${ }^{1,2}$, Lalu Muliyadi ${ }^{2}$ \\ ${ }^{1}$ Physics Education, Faculty of Teacher Training and Education, University of Mataram, Lombok, West Nusa Tenggara, Indonesia. \\ ${ }^{2}$ Master of Science Education Program, University of Mataram, Lombok, West Nusa Tenggara, Indonesia.
}

DOI: $\underline{10.29303 / \text { ippipa.v7i1.461 }}$

\section{Article Info}

Received: August 13, 2020

Revised: November $8^{\text {th }}, 2020$

Accepted: Novembr 16 $16^{\text {th }}, 2020$

\begin{abstract}
The synthesis of M-hexaferrite with metal doping $\mathrm{Co}\left(\mathrm{BaFe}_{12-3 x} \mathrm{Co}_{x} \mathrm{O}_{19}\right)$ based on natural iron sand at Ketapang beach in Pringgabaya Subdistrict, East Lombok using the coprecipitation method has been successful. The basic ingredients used in this study were natural iron sand and BariumCarbonate $\left(\mathrm{BaCO}_{3}\right)$ powder, while the doping material used was Cobalt (II) Chloride Hexahydrate $\left(\mathrm{CoCl}_{2} \cdot 6 \mathrm{H}_{2} \mathrm{O}\right)$ powder with a variety of mole fraction $(\mathrm{X}=0.0,0.2,0.4,0.6,0.8$ and 1.0$)$. The solvent uses $37 \%$ hydrochloric acid $(\mathrm{HCl}), 25 \%$ $\mathrm{NH}_{4} \mathrm{OH}$ solution, and distilled water. The sample formed was then calcined at $200{ }^{\circ} \mathrm{C}, 400$ ${ }^{\circ} \mathrm{C}, 600{ }^{\circ} \mathrm{C}, 800{ }^{\circ} \mathrm{C}$ and $1000{ }^{\circ} \mathrm{C}$. The resulting sample shows that there is an effect of Co doping and calcination temperature in the formation of barium M-hexaferrite. The higher the mole fraction of Co doping ions and the calcination temperature, the darker the color of the powder produced.
\end{abstract}

Keywords: Barium M-hexaferrite; cobalt (Co); coprecipitation.

Citation: Susilawati, S., Doyan, A., \& Muliyadi, L. (2020). Synthesis of M-Hexaferrites Material Based on Natural Iron Sand with Metal Co Doping Using the Coprecipitation Method. JPPIPA (Jurnal Penelitian Pendidikan IPA), 7(1), 1-4. doi:https://doi.org/10.29303/ippipa.v7i1.461.

\section{Introduction}

The use of electromagnetic waves has been widespread in various fields such as electronics, telecommunications, and information. This results in increased pollution of electromagnetic waves in the form of microwave radiation which can interfere with the environment. Electromagnetic wave radiation that exceeds the limit can disrupt the environment, especially human health (Susilawati et al, 2015). In response to this problem, scientists have developed absorption technology for microwave radiation. Certain types of materials can be used for this technology. One of the materials that can be used as a microwave absorbent material is Barium M-Hexaferrite (Doyan et al, 2015).
Barium M-Hexaferrite $(\mathrm{BaM})\left(\mathrm{BaFe}_{12} \mathrm{O}_{19}\right)$ has a hexagonal molecular structure, high saturation magnetization (78 emu/g), high coercivity field (6700 Oe) (Saidah et al, 2012). The high magnetic strength (coercivity field) causes the absorption property of BaM to be weak, making it less effective to use as a microwave absorbing material. To solve this problem, it is necessary to substitute or dop it to reduce the magnetic properties of $\mathrm{BaM}$ from a strong magnet to a weak magnet. BaM, which is weakly magnetic, has a wide application as an absorbent material for electromagnetic waves (Bhattacharya et al, 2014).

This research concentrates the formation of $\mathrm{BaFe}_{12} \mathrm{O}_{19}$ doped with metal $\mathrm{Co}$ with variations in doping and calcination temperature to produce $\mathrm{BaFe}_{12}$ ${ }_{x} \mathrm{Co}_{x} \mathrm{O}_{19}$ which can be used as a microwave absorber. 
This study aims to determine the characteristics of Co metal dopant administration and the temperature of barium M-hexaferrite $\left(\mathrm{BaFe}_{12-\mathrm{x}} \mathrm{Co}_{\mathrm{x}} \mathrm{O}_{19}\right)$ on phase formation.

Several methods that can be used in the manufacture of barium M-hexaferrite include the mechanical method of milling, sol-gel, and coprecipitation (Khairunnisa et al, 2018). Among the three methods, the coprecipitation method is a method that has a high level of purity (Susilawati et al, 2013), so that in this study a synthesis was carried out using the coprecipitation method.

\section{Method}

Synthesis of M-hexaferrite with Co doping metal $\left(\mathrm{BaFe}_{12-\mathrm{x}} \mathrm{Co}_{x} \mathrm{O}_{19}\right)$ using the coprecipitation method (Susilawati et al, 2016). The basic ingredients in this study were natural iron sand (Ketapang Beach area, Pringgabaya District, East Lombok), and Barium Carbonate $\left(\mathrm{BaCO}_{3}\right)$ powder, while the doping material used was Cobalt (II) Chloride Hexahydrate $\left(\mathrm{CoCl}_{2} \cdot 6 \mathrm{H}_{2} \mathrm{O}\right)$ powder. The solvent uses $37 \%$ hydrochloric acid $(\mathrm{HCl}), 25 \% \mathrm{NH}_{4} \mathrm{OH}$ solution, and distilled water. The synthesis of $\mathrm{BaFe}_{12-x} \mathrm{Co}_{x} \mathrm{O}_{19}$ was carried out by varying the Co doping mole fraction $(\mathrm{x}=$ $0.0,0.2,0.4,0.6,0.8$, and 1.0) and variations in calcination temperature $\left(\mathrm{T}=200{ }^{\circ} \mathrm{C}, 400{ }^{\circ} \mathrm{C}, 600{ }^{\circ} \mathrm{C}, 800\right.$ ${ }^{\circ} \mathrm{C}$ and $1000{ }^{\circ} \mathrm{C}$ ) (Susilawati et al, 2018)

\section{Result and Discussion}

Synthesis of M-hexaferrite with metal Co doping $\left(\mathrm{BaFe}_{12-\mathrm{x}} \mathrm{Co}_{x} \mathrm{O}_{19}\right)$ using the coprecipitation method includes material separation and synthesis processes. The iron sand separation process aims to separate magnetic material from natural iron sand (Susilawati et al, 2015). The natural iron sand separation process is shown in Figure 1.

Figure 1. The natural iron sand separation process.

This process is carried out by sieving natural iron sand first to separate the sand from the gravel so that a fine texture is obtained and then separated by using a permanent magnet with a strength of $3.6 \mathrm{~T}$ to separate the magnetic material from natural sand then weighed and calculated the percentage of magnetic material. obtained (Susilawati et al, 2018).

The synthesis of $\mathrm{BaFe}_{12-\mathrm{x}} \mathrm{Co}_{\mathrm{x}} \mathrm{O}_{19}$ made from natural iron sand was carried out with variations in the mole fraction of Co doping ion $(x=0.0,0.2,0.4,0.6,0.8$, and 1.0) and variations in calcination temperature ( $\mathrm{T}=$ $200{ }^{\circ} \mathrm{C}, 400{ }^{\circ} \mathrm{C}, 600^{\circ} \mathrm{C}, 800^{\circ} \mathrm{C}$ and $1000^{\circ} \mathrm{C}$ ). This process begins with dissolving the basic ingredients of natural iron sand with $\mathrm{HCl}$ then stirring with a magnetic stirrer on a hot plate with a temperature of $80^{\circ} \mathrm{C}$ for one hour and dissolving $\mathrm{BaCO}_{3}$ with distilled water then stirring with a magnetic stirrer on a hot plate at room temperature for two hours. Then the natural iron sand solution is mixed with $\mathrm{BaCO}_{3}$ so that it is brownishblack and added with the doping material. Furthermore, the mixture is dripped with $\mathrm{NH}_{4} \mathrm{OH}$ to obtain a homogeneous precipitate (Figure 2).

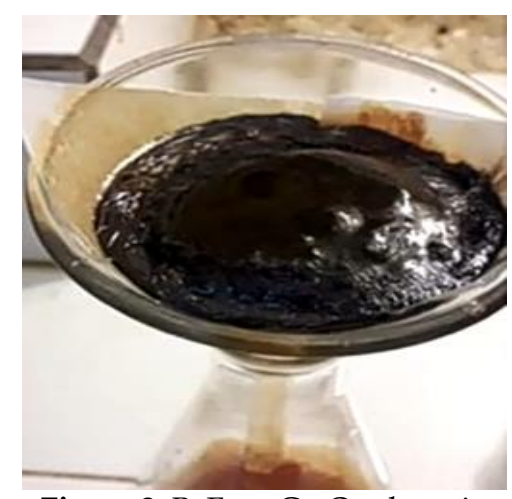

Figure 2. $\mathrm{BaFe}_{12-\mathrm{x}} \mathrm{Co}_{\mathrm{x}} \mathrm{O}_{19}$ deposit.

The precipitate formed is filtered with filter paper then washed with distilled water until the $\mathrm{pH}$ is neutral (Susilawati et al, 2015). The neutral sample was then dried in an oven at $80{ }^{\circ} \mathrm{C}$ and crushed until smooth. The next process is calcining the sample at a temperature of $200{ }^{\circ} \mathrm{C}, 400{ }^{\circ} \mathrm{C}, 600{ }^{\circ} \mathrm{C}, 800{ }^{\circ} \mathrm{C}$ and 1000 ${ }^{0} \mathrm{C}$ for two hours (Figure 3 ).

Figure 3. The process of calcining the $\mathrm{BaFe}_{12-\mathrm{x}} \mathrm{Co}_{x} \mathrm{O}_{19}$ sample. 
The calcined sample is then crushed again to form $\mathrm{BaFe}_{12-\mathrm{x}} \mathrm{Co}_{\mathrm{x}} \mathrm{O}_{19}$ powder as shown in Figures 4 and 5 .

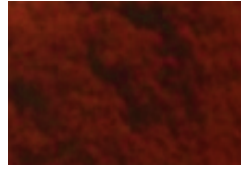

(a)

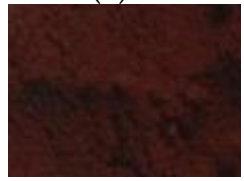

(d)

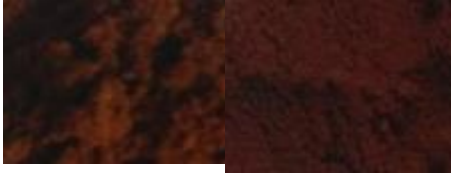

(b)

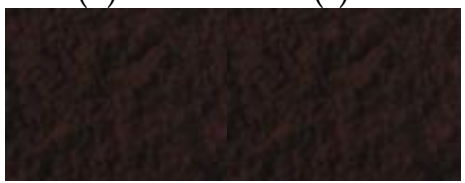

(e)
Figure 4. Sample $\mathrm{BaFe}_{12-3 x} \mathrm{Co}_{x} \mathrm{O}_{19}\left(200^{\circ} \mathrm{C}\right)$ doping variation $\mathrm{Co}$ (a) $x=0.0$, (b) $x=0.2$, (c) $x=0.4,(d) x=0.6,(e) x=0.8$, (f) $x=$ 1.0 .

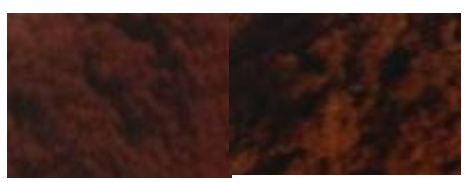

(a)

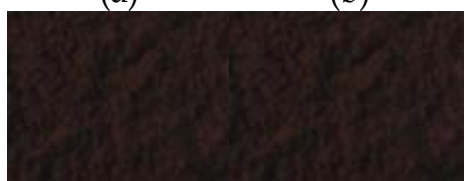

(d)

(e)

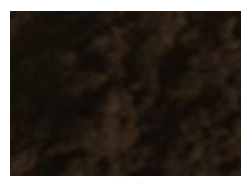

(c)
Figure 5. Sample $\mathrm{BaFe}_{12-\mathrm{x}} \mathrm{Co}_{\mathrm{x}} \mathrm{O}_{19}(\mathrm{x}=0.8)$ calcination temperature variation a) $200^{\circ} \mathrm{C}$, (b) $400{ }^{\circ} \mathrm{C}$, (c) $600^{\circ} \mathrm{C}$, (d) $800^{\circ} \mathrm{C},(\mathrm{e}) 1000^{\circ} \mathrm{C}$.

Figure 4 shows a sample of $\mathrm{BaFe}_{12-3 x} \mathrm{Co}_{x}\left(200^{\circ} \mathrm{C}\right)$ doping variation. In the figure, it is clear that there is a color difference in the sample caused by the doping of metal Co. The higher the mole fraction of metal Co doping, the darker the color of the resulting sample will be (Susilawati et al, 2015). This is due to the doping of metal $\mathrm{Co}$, mixing the solution will produce a darker color and the volume of $\mathrm{NH}_{4} \mathrm{OH}$ needed to precipitate the sample is higher along with the increase in the mole fraction of the doping ion (Susilawati et al, 2018).

Figure 5 shows the sample $\mathrm{BaFe}_{12-\mathrm{x}} \mathrm{Co}_{x} \mathrm{O}_{19}$ calcination temperature variations. The higher the calcination temperature, the darker the color of the resulting sample. This is because the solvent used has evaporated due to the calcination process (Susilawati et al, 2019). Calcination aims to remove water content, solvents, and impurities such as $\mathrm{CO}_{2}$ from barium carbonate $\left(\mathrm{BaCO}_{3}\right)$ as it will affect the purity of the sample (Susilawati et al, 2017).

\section{Conclusion}

The synthesis of barium M-hexaferrite based on natural iron sand (Ketapang Beach area, Pringgabaya
District, East Lombok) was successfully carried out using the coprecipitation method. The results of the synthesis show that there is an effect of metal doping and calcination temperature in the formation of barium M-hexaferrite. The higher the mole fraction of Co doping ions and the calcination temperature, the darker the color of the powder produced.

\section{Acknowledgements}

To all parties who have helped to materialize this article and this research has been funded by a superior research grant from Menristek Dikti for the 2020 budget year. We also extend our thanks to the Analytical Laboratory of the University of Mataram and other parties who have provided input and critical review to improve this paper.

\section{References}

Bhattacharya, Dhibar, P., Hatui, S., Mandal, G., Das, A., \& Das, CK. 2014. Graphene Decorated with hexagonal Shaped M-type ferrite and polyaniline wrapper: A potential candidade for electromagnetic wave absorbing and energy storage device applications. RSC Adv. 4, 17039.

Doyan, A., Susilawati, \& Halik, I. 2015. Characterization of Electrict and Magnetict Priperties of Barium M- Hexaferrites Doped with Zinc. Procedia ICMSE, University of Mataram, Lombok Island, Indonesia, Nov. 4-5.

Khairunnisa, Susilawati, Savalas, R.T., Taufik, M., \& Wahyudi. 2018. Sintesis Bahan M-Hexaferrites dengan Doping Logam Co Menggunakan Metode Kopresipitasi. Jurnal Penelitian Pendidikan IPA, 4(1), 75-80.

Saidah, I. N, \& Zainuri, M. 2012. Effect of pH Variation of $\mathrm{HCl}$ Solvent on Barium Synthesis MHexaferrite With Doping Zn (BaFe11, 4Zn0,6O1 9) Using Coprecipitation Method. Jurnal Sains dan Seni ITS, 1 (1), $41-46$.

Susilawati, Doyan, A., Taufik, M., Wahyudi, Gunawan, E.R., Fithriyani, A, \& Nazarudin. 2019. Characterization of Barium M-Hexaferrite with Doping $\mathrm{Zn}$ and $\mathrm{Mn}$ for Microwaves Absorbent. Materials Science Forum, 966, 282-289.

Susilawati, Khairunnisa, \& Doyan, A. 2018. Sintesis Bahan M-Hexaferrites dengan Doping Logam Co Menggunakan FTIR. Jurnal Pendidikan Fisika dan Teknologi, 1(3), 180-184.

Susilawati, Doyan, A., Taufik, M., Wahyudi, Gunawan, E.R., Kosim, Fithriyani, A., \& Khair, H. 2018. Identifikasi Kandungan Fe Pada Pasir Besi Alam di Kota Mataram. Jurnal Pendidikan Fisika dan Teknologi, 4(1), 105-110. 
Susilawati, A. Doyan, H. Khair, M Taufik, \& Wahyudi. 2018. Electrical, Magnetic and Microwave Absorption Properties of M-type Barium Hexaferrites (BaFe1 2-2xCoxNixO19). IOP Conf. Series:Journal of Physics: Conf. Series, 1011, 012009.

Susilawati, Doyan, A., Taufik, M., \& Wahyudi. 2018. Synthesis and Characterization of Barium MHexaferrite with Metal Doping $\mathrm{Mn}$ and $\mathrm{Ni}$ for Microwaves Absorbent. Journal of Physics: Conference Series, 1120, 012002, 1-8.

Susilawati, Doyan, A., \& Sahlam. 2017. Synthesis and Characterization Materials M-Barium Hexaferrite Doping Ions Co-Mn Nano Particle. IOP Conf. Series: Materials Science and Engineering, 196, 012016.

Susilawati, Doyan, A., \& Khaililurrahman. 2016. Synthesis and Characterization of Barium Hexaferrite with Manganese (Mn) Doping Material as Anti-Radar. American Institute of Physics Conf. Proc. 1801, 040007.

Susilawati, Munib, \& Doyan, A. 2015. Pengaruh Temperatur Kalsinasi Dan Subsitusi Logam Nikel Pada Pembentukan Fasa Barium M-Hexaferritte $\left(\mathrm{BaFe}_{12-\mathrm{x}} \mathrm{Ni}_{\mathrm{x}} \mathrm{O}_{19}\right)$ Menggunakan FTIR. J. Pijar MIPA, 10(1), 31-36.

Susilawati, Doyan A, \& Munib M, 2015 Synthesis by Co-precipitation Method and Characterization of Nickel-doped Barium M-Hexaferrite $\left(\mathrm{BaFe}_{12} \mathrm{O}_{19}\right)$ Proceeding ICMSE ISBN9786021570425. 